\title{
AS TESSITURAS DA MEMÓRIA: FICÇÕES E TESTEMUNHOS
}

\author{
Andréa Figueiredo Leão Grants* \\ Izabele Cristini da Silva** \\ Jair Zandoná \\ Leticia Goellner ${ }^{* * * *}$ \\ Stélio Furlan ${ }^{* * * * *}$ \\ Universidade Federal de Santa Catarina
}

Para justificar a tessitura do mais recente número da revista Anuário de Literatura, que chega ao seu segundo número do décimo nono volume e conta com treze artigos, uma tradução e uma resenha, a capa apresenta a tela Pescadores (1970), de Sílvio Pléticos, para quem "a vida é uma linha".

A revista se abre com o artigo Ficções de escritores fictícios, de Claudia Maria Pereira Almeida, que discorre sobre a noção de autor a partir da presença recorrente de autores-personagens na literatura contemporânea, no caso, em Le Coeur de Marguerite (1999), de Vassilis Alexakis e Pseudo (1976), de Romain Gary. Em seguida, Dionei Mathias em Fragmentos e estilhaços em "Die Prärie", de Zafer Şenocak encontra na fragmentação da pertença, de sentido e da própria narração, sofrida e encenada pelo protagonista Sascha, um fio condutor para amarrar suas reflexões. E, fechando a primeira seção, formada por pesquisadores docentes, em A escrita gendrada do gaucho nas narrativas transgressoras de Silvina Ocampo, Rafael Eisinger Guimarães propõe uma leitura crítica dos contos "La hija

EY NC ND Esta obra está licenciada sob uma Licença Creative Commons.

\footnotetext{
* Doutoranda e Mestre em Literatura pela UFSC. Bibliotecária do Sistema de Bibliotecas da UFSC. Coordenou o Portal de Periódicos UFSC (2009/jun.2014). Integra a Comissão Editorial da Anuário de Literatura.

** Mestranda do Programa de Pós-Graduação em Literatura da UFSC e integra a Comissão Editorial da Anuário de Literatura.

*** Doutor em Literatura pela UFSC, integra a Comissão Editorial da Anuário de Literatura.

**** Doutoranda no Programa de Pós-Graduação em Estudos da Tradução na UFSC. Colabora no periódico Cadernos de Tradução. Integra a Comissão Editorial da Revista Anuário de Literatura.

***** Doutor pela Universidade Federal de Santa Catarina. Atualmente é Professor Associado junto ao DLLV/UFSC. Atual Editor-Chefe da Revista da ANPOLL e Editor da Revista Anuário de Literatura.
} 
del toro", publicado em Las invitadas (1961) e "La muñeca", que consta no livro Los días de la noche (1970), para reivindicar uma ruptura no cânone da gauchesca por meio de uma escrita marcada por questões de gênero.

Na segunda seção, em Entre a memória e o silêncio, o testemunho tardio de um deportado homossexual, Marcelo Spitzner analisa a biografia de Rudolf Brazda escrita por Jean-Luc Schwab sugerindo que esta narrativa se configura enquanto embate contra o esquecimento, o silenciamento e reconstituição dos limites da narrativa histórica. Por sua vez, Carina Marques Duarte, em Entre memória e esquecimento: a formação das identidades em Nosso musseque e Venenos de Deus, remédios do diabo, avalia a constituição identitária de Angola e Moçambique nas obras de Luandino Vieira e Mia Couto reivindicando para o primeiro uma noção de escrita literária que afirma o papel da memória como meio de preservação do passado e da tradição e, para o segundo, a importância do esquecimento na construção da nação. Na sequência, no artigo Memórias do salazarismo em o "Vale da Paixão", de Lídia Jorge, Mariana Jantsch Souza e Alfeu Sparemberger investigam, a partir da perspectiva das memórias pós-ditadura, elementos que traem as simetrias entre os sistemas familiar e estatal-ditatorial e avaliam o papel do salazarismo na constituição da narrativa. Em Gostaríamos de informá-lo de que amanhã seremos mortos com nossas famílias: invisibilidade e testemunho, Daniela Werneck Ladeira Werneck reflete sobre o testemunho de um trauma coletivo, em especial os da etnia tutsi durante e após o genocídio de 1994, assunto do livro-reportagem de Philip Gourevitch. No artigo Uma poética do silêncio: trauma, representação e linguagem em "Fuga da morte", de Paul Celan, Maria Esther Torinho investiga as estratégias poéticas mobilizadas neste texto enquanto maneira de enfrentar a aporia entre trauma e representação, inserindo-o no contexto da literatura de testemunho. E Greicy Bellin, com o artigo Machado de Assis e a imprensa periódica: uma análise de "Confissões de uma viúva moça", parte da análise do conto para evidenciar a atuação de Machado na imprensa periódica do Rio de Janeiro no início de sua carreira literária, mote para investigar o estatuto do jornal e da formação do público leitor na sociedade brasileira oitocentista, procurando compreender o papel dos periódicos na publicação e circulação de obras literárias e o perfil dos leitores do Jornal das Famílias. Diego Moreira, em As escolhas de Auerbach: uma questão de realidade, centra o investimento discursivo no capítulo sobre Dom Quixote, em Mimesis: a representação da realidade na literatura ocidental (1946), de Erich Auerbach, questionando a tentativa "abertamente conservadora" de resgatar uma tradição cultural europeia que se havia perdido com o advento da $1^{\mathrm{a}}$ e $2^{\mathrm{a}}$ Guerras Mundiais. 
Escrito a seis mãos, em A alma cheia de bandeiras: ressignificação política e permanência de uma canção latino-americana, de Camila Marchesan Cargnelutti, Maurício Marques Brum e Anselmo Peres Alós, analisa-se a canção El alma llena de Banderas, escrita pelo cantor e compositor chileno Victor Jara relacionando-a ao contexto histórico, político e social em que ela foi criada, com o intuito de compreender suas possibilidades de ressignificação e apropriação em novas conjunturas latino-americanas. A sua vez, no artigo Imagens de um corpo poe(ró)tico digitalizado, Adriana Carolina Hipólito de Assis objetiva verificar em algumas obras de Décio Pignatari um corpo poético que se lê enquanto aparato comunicacional, midiático em confluência à concepção da arte como imagem digitalizada, “como corpo sensório, tátil, erotizado", afirma. A presente sessão se fecha o artigo de Katrym Aline Bordinhão dos Santos, intitulado Mistérios de Lisboa e sua adaptação cinematográfica, cuja análise contrastiva põe em cena o romance de Camilo Castelo Branco e a adaptação cinematográfica homônima do romance avaliando as especificidades de cada mídia e os efeitos obtidos com seus usos, principalmente no que diz respeito às escolhas imagéticas para a transposição de elementos típicos da escrita do autor português, tais como a organização folhetinesca e o uso de metalinguagem.

E, como arremate deste número, temos uma tradução de Pedro Falleiros Heise, a saber, O proêmio da Genealogia Deorum Gentilium, de Giovanni Boccaccio, e uma resenha intitulada Regionalismus - Regionalismos: subsídios para um novo debate, de André Tessaro Pelinser, por Letícia Malloy.

Considerando a relevância acadêmica do conjunto de textos aceitos para publicação, é com satisfação que apresentamos estas páginas de crítica e teoria literária, não sem deixar um sincero agradecimento à equipa de avaliadores ad hoc e ao Conselho Consultivo, pelas acuradas avaliações, bem como aos autores e autoras que nos honraram com a escolha da revista Anuário de Literatura para a divulgação de seus textos. Registramos, por fim, um agradecimento especial ao artista plástico Sílvio Pléticos, nascido em Pula, Iugoslávia, em 1924, e residente em Florianópolis desde 1968, pela oferta da tela Pescadores (1970), significativo paratexto desta revista. Na esperança de que este número possa suscitar fecundos diálogos, resta lhes desejar boas leituras. 